\title{
EM NOME DA DECÊNCIA
}

Goffredo da Silva Telles Júnior Professor Emérito da FDUSP

O sonho, o ideal, o pensamento do futuro. A vontade de agir, de realizar, de construir. $\mathrm{O}$ anseio de interferir na marcha dos acontecimentos, para corrigir os rumos, dar ao Brasil a seriedade perdida. A determinação de repudiar a corrupģão institucionalizada, de protestar contra ela e de lutar para aniquilá-la. O propósito de não transigir com a patifaria generalizada, de näo cooperar em seus desígnios, nem mesmo com o silêncio, a abstenção, o recolhimento, a fingida indiferença. A decisão de não tolerar o preceito do "levar vantagem em tudo", que é a ética da esperteza, da astucia, do sem-vergonhismo, da trapaça. A resolução de denunciar e combater o suborno, a negociata, a depravação, na área dos serviços e negócios públicos. A disposição de renegar e repelir, nas atividades políticas, a displicência criminosa, o desprezo pela opinião pública, o atentado à moral, o desrespeito à Constituição.

Tudo isto é o que nos apaixona neste instante. É o que proclamamos, a tútulo de manifesto, em nome da dignidade do ser humano e da ressurreição dos bens soberanos das pessoas. Em nome da Decência, da Honradez, da Justiça, da Fraternidade, da Beleza.

Como Patrono da Turma, venho trazer meu abraço comovido. Mas eu gostaria que este abraço tivesse um sentido especial. Eu gostaria que este abraço tivesse o valor de um vínculo. Vamos unir nossos coraçōes. Vamos formar uma grande Aliança. Vamos constituir uma Frente, pela reabilitação moral da nossa Terra.

Aqui estamos juntos, numa noite de festa.

É como se estivessemos em nosso Páteo das 20 Arcadas; no Páteo evocativo de tantas campanhas pela liberdade.

É como se estivéssemos no Território Mágico da eterna Academia.

A nossa Aliança é a Aliança do Páteo, a Aliança do Território Livre. É um prolongamento da Aliança de nosso Círculo das Quartas-Feiras.

Daqui é que devemos partir, levando conosco, por toda parte, a tocha acesa de nosso inconformismo, de nosso ímpeto de renovação e renascimento.

Pela determinação, que nos há de congregar, transmudaremos nossas desilusōes numa afirmação de esperança.

Tenho noção clara de que estaremos nos colocando na contramão das tendências de uma mentalidade cada vez mais difundida no País de hoje.

Mas, precisamente, o de que precisamos é uma insurreição!

- Discurso do Patrono, pronunciado em 11 de dezembro de 1989, na solenidade de Formatura da Turma "Centenário da República", da Faculdade de Direito da Universidade de São Paulo. A sessão foi realizada no Palácio das Convençōes do Anhembi. 
E nossa insurreição estará toda voltada para o futuro. O que almejamos é influir na obra de construção de um Brasil diferente. O que não queremos, para o Brasil, é um futuro que seja uma simples repetição de um passado recente, uma simples continuação de um preșente sombrio. Não queremos um País corroído pela safadice e pelo cinismo, marcado pelo desfibramento do caráter e pela sinistra inversão dos valores morais.

Haverá, certamente, os que vão rir de nós. Vão rir os descrentes, os céticos, os desiludidos, os cansados.

Haverá, também, os que passarão por nós, com seus ares de superioridade maliciosa, ou com olhos de ódio, porque estaremos atrapalhando os seus negócios.

Haverá os que vão nos chamar de "sábios" ou de "poetas", de habitantes da fantasia de "Don-Quixotes da República". É que sempre se manifestarão os que se deixaram arrastar pela onda deletéria do meio circundante. Sempre hão de aparecer, como é óbvio, os que caíram em tentação, e calculadamente optaram pela filosofia do "vale-tudo", quando se trata de conquistar poder e os gozos da vida.

Mas haverá - ninguém duvide! - nos mais diversos setores do território nacional, multidōes de brasileiros aflitos, aflitos como nós, pensando como nós, e que somente aguardam uma oportunidade para reclamar sua revolta e sua esperança. Esses nos entenderão. Esses virão formar conosco, na FRENTE que acabamos de constituir.

Alguns dirão, quem sabe, que nosso ideal é lindo, mas é um sonho. Responideremos que sim: nosso ideal é um sonho. É um sonho de decência, um sontio de seriedade, um sonho de beleza.

De fato, pertencemos à legião que acredita no poder extraordinário do sonho, na força revolucionária dos ideais de pureza, para mudar os rumos da historia e para construir o futuro.

Triste é o povo que haja perdido a chama encantada de seus sonhos!

Aqui estamos reunidos, filhos da Academia do Largo de São Francisco. Vamos firmar nossa Aliança, em torno de um sonho. Vamos erguer uma Frente, em defesa da Decência. Em defesa daqueles bens espirituais, que são a alma e o valor de nossos diplomas de bacharéis em Direito.

Esta é a frente que vai construir um Brasil moderno, um Brasil sério, um Brasil disposto a realizar as reformas de fundo, que os ideais da justiça aconselham.

Esta é a frente que vai construir um Brasil atento aos movimentos sociais da atualidade.

Nós sabemos - nós bacharéis do Largo - nós sabemos que o capitalismo brasileiro é tão obsoleto, tão atrasado, quanto o primitivo socialismo, anterior à perestroika. Nós sabemos que o capitalismo daqui e o coletivismo militarizado de lá levam à miséria e à fome.

Vamos formar a Aliança do Bom-Senso Nacional, para derrubar o muro entre a riqueza desmedida e a miséria total, antes que a fome e o desespero ponham fogo no Brasil.

Vamos formar a Aliança do Entendimentro Nacional, com abertura franca entre o Poder Executivo e a imensa coletividade dos trabalhadores e empresários de todas as categorias econômicas e culturais da Nação. 
Vamos formar a Aliança pelo Desenvolvimento. Mas o desenvolvimento dessa Aliança não pode ser o desenvolvimento selvagem do obsoleto capitalismo individualista. $O$ desenvolvimento dessa Aliança há de ser rigorosamente planejado, para que a riqueza produza o que é necessário para extinguir a miséria triste dos departamentos.

Vamos formar a Frente Ética da Mudança. Mas a mudança que nos referimos não pode ser a mudança apregoada pelos delfins dos fisiologismos dominantes. Não pode ser a mudança dos "coronéis", a mudança daqueles que usam a palavra mudança, para resistir à mudança. Não pode ser a "mudança seletiva", que só vai servir aos que estão por cima."

Nosso sonho de mudança traz a marca de nosso Páteo. Tem a perene ressonância de nosso Território Livre.

Nossa mudança se inspira na compreensão humana, na solidariedade, na generosidade, num profundo sentimento de fraternidade.

Nossa mudança se inspira nos mesmos ideais que levantaram a nossa Faculdade, na luta contra a escravatura; nas guerras contra o arbítrio e o despotismo; nos movimentos pela constitucionalização do País e pelo Estado de Direito; na campanha das "Diretas-já".

Nós, bacharéis do Largo de São Francisco, não toleramos mais a riqueza escondida dos multimilionários, ao lado da fome dos miseráveis. Não toleramos mais as imensidões de terras desocupadas ao lado dos que não têm quatro ou cinco hectares para plantar o arroz, o feijão, o milho. Não agüentamos mais o fantasma da dívida externa, que nem sequer sabemos em quanto monta, nem como negociá-la com os banqueiros. Não suportamos mais os fracassos sucessivos dos planos econômicos, como, por exemplo, a atual vergonha do programa do álcool. Não toleramos mais a corrupção nos órgãos do governo e nas Estatais; a impunidade escandalosa dos delinqüentes de colarinho branco.

Vamos formar uma frente de revolta contra o analfabetismo crescente de nosso povo, e contra o desamparo e a angústia das populações carentes.

Aqui estamos reunidos, nesta noite de festa. Vim trazer-lhes meu abraço: o abraço de minha infinita gratidão, e meu abraço de exortação e estímulo.

Os arquitetos dão o nome de abraço ao entrelaçamento das folhagens de pedra, esculpidas em volta de uma coluna.

Com minha eleição para Patrono desta Turma, ficamos nós todos abraçados, ficamos entrelaçados, em torno da coluna de nossas conviç̧ões.

Bacharéis de 89! Eu os saúdo e felicito! Pertencemos à mesma familia, à familia espiritual da Velha e sempre Nova Academia!

Aqui vim trazer-lhes meu abraço, o abraço de um estudante de Direito, que conhece o papel do Direito na crônica da Liberdade.

Este quente abraço é o sinal de nossa Aliança.

Nossa Aliança é realidade viva e é sonho.

Haverá os que vão rir dos sonhadores da moderna Democracia.

Que importa?

* Ver José Neumanne, O muro da Belindia, in O Estado de S. Paulo, de 06/12/89. 
Eu por mim, prefiro ser o sonhador da fraternidade universal, a ser poderosa engrenagem na maquinaria do capitalismo desumano.

Queridos companheiros! Queridos bacharéis! Nesta noite, que é quase noite de Natal, recebam o abraço fiel de um advogado.

Recebam o forte abraço de um trabalhador. Recebam o abraço encantado de um homem livre. 